\title{
Genetic variation of agarwood producing tree (Gyrinops versteegii) from Pongkor, Manggarai District, Flores Island, Indonesia using ISSR molecular markers
}

\author{
ALFI FAUZAN IRSYAD ${ }^{1}$, RIDESTI RINDYASTUTI ${ }^{2, \bullet 凶}$, TITUT YULISTYARINI ${ }^{2}$, AGUNG SRI DARMAYANTI ${ }^{2}$, \\ BUDI SETIADI DARYONO, \\ ${ }^{1}$ Laboratory of Genetics and Breeding, Faculty of Biology, Universitas Gadjah Mada. Jl. Teknika Selatan, Sekip Utara, Sleman 55281, Yogyakarta, \\ Indonesia. Tel.: +62-271-580839, Fax.: +62-271-6492355. "email: bs_daryono@ mail.ugm.ac.id \\ ${ }^{2}$ Purwodadi Botanic Gardens, Research Centre for Plant Conservation and Botanic Gardens, Indonesian Institute of Sciences. J1. Raya Surabaya-Malang \\ Km. 65, Purwodadi, Pasuruan 67163, East Java, Indonesia. Tel.: +62-343-615033, Fax.: +62-341-426046. "email: ride17@ gmail.com
}

Manuscript received: 27 November 2019. Revision accepted: 10 December 2019.

\begin{abstract}
Irsyad AF, Rindyaastuti R, Yulistyarini T, Darmayanti AS, Daryono BS. 2020. Genetic variation of agarwood producing tree (Gyrinops versteegii) from Pongkor, Manggarai District, Flores Island, Indonesia using ISSR molecular markers. Biodiversitas 21: $x x x x$. Agarwood is a black-colored tree wood that produces distinctive sap because of fungal infections which belong to Thymelaeaceae family (mainly Aquilaria and Gyrinops). Agarwood product is highly valuable that leading to over exploitations by the collectors. To develop the most effective and efficient conservation strategies, genetic information from these plants is required. The aims of this research are to determine the genetic variation and to confirm the species identity of agarwood producing tree (Gyrinops versteegii (Gilg.) Domke) population in Pongkor Community Forest, Pongkor, Manggarai District, Flores Island, East Nusa Tenggara. Information of the genetic variation, as well as the phenetic relatedness, were evaluated with inter-simple sequence repeat molecular marker (ISSR) using five primers; $\mathrm{Ng} 2.01, \mathrm{Ng} 2.06, \mathrm{Ng} 3.01, \mathrm{Ng} 3.02$, and UBC 855, with two other agarwood producing species as outgroup (Aquilaria filaria and Gyrinops decipiens). Amplified bands from all primers showed $55.17 \%$ polymorphic bands in G. versteegii. Genetic variation of $G$. versteegii identified with Nei's genetic diversity (h value) obtained at 0.218 . Clustering analysis from UPGMA dendrograms formed three major clusters. Degree of similarity of G. versteegii based on the dendrograms obtained at $85.9 \%$ using SSM method. The results showed close phenetic relatedness between individuals and relatively high genetic variation of G. versteegii, however, imply the need for strictly maintenance of habitat preservation and larger population size.
\end{abstract}

Keywords: Agarwood, Gyrinops versteegii, genetic variation, ISSR, heterozygosity

\section{INTRODUCTION}

Agarwood is a black-colored tree wood that produces distinctive sap from various tree species that mostly belong to the Aquilaria genus. Agarwood is a part of sapwood which was infected by fungal microbes (usually Phialophora parasitica) that change the color of the agarwood producing tree from pale and brightly colored into dark and blackish (Akter et al. 2013; López-Samson and Page 2018). Agarwood has a very high economic value which is widely processed into perfumes and fragrances because of its distinctive aroma (Zich and Compton 2001; Turjaman et al. 2016). Moreover, agarwood producing trees could also be used as various medicines (Dahham et. 2016; Okugawa et al. 1993), an ingredient in sculpture, although it is rarely used in such way (Barden and Anak 2002). The quality of agarwood is determined by several factors, including the plant species, geographical location, parts of tree such as roots, stems, branches, the infection duration, as well as how it is harvested (López-Samson and Page 2018).

The high economic values of agarwood cause the producing tree to become vulnerable to exploitation, which was indicated by the decreasing product quality and quantity. The decline has caused the agarwood-producing trees are listed in Appendix II of Convention on International Trade in Endangered Species of Wild Fauna and Flora (CITES) (CITES 2017). One of the listed species is Gyrinops versteegii (Gilg.) Domke, which is an agarwood-producing species originated from West Nusa Tenggara and East Nusa Tenggara regions, Indonesia (Sidiyasa 1986; Roemantyo and Partomiharjo 2010).

Decreasing population of agarwood producing trees can be overcome by conservation programs to maintain the existence of plant and its sustainability use for resinous products or medicines. In formulating the proper and effective conservation strategies, genetic information from related organisms is required (Sitepu et al. 2011; Turjaman and Hidayat 2017). Genetic identification is the first step to provide information as a reference in conservation management of organisms. This genetic identification is generally carried out molecularly using molecular marker technique.

One of molecular marker techniques included in the genetic study is Inter Simple Sequence Repeat (ISSR). This method amplifies the microsatellite, which is a sequence consisting of two to seven nitrogen bases in the DNA strand and repeatedly (Richard et al. 2008; Semagn et al. 
2006). The ISSR method has several advantages, some of which are it does not require a sequence data in primary construction, the amount of DNA template needed is quite low because the analysis procedure only includes Polymerase Chain Reaction (PCR), and the process is randomly distributed throughout the genome (Godwin et al. 1997). Moreover, ISSR has been proven as successful method to evaluate intra-species genetic variation (Daryono et al. 2019). The genetic identification can provide information on species relatedness, population origin of the organism, and the estimation of the number of individuals in a population as the results. The genetic identification also assists in monitoring activities of endangered species (Allendorf et al. 2013). Molecular markers were widely used for genetic identification of agarwood producing species, such as G. versteegii from Papua using RAPD method (Siburian et al. 2017), G. versteegii from Lombok using RAPD markers (Widyatmoko et al. 2009), Aquilaria malaccensis using ISSR markers (Banu et al. 2015), natural Aquilaria populations in Peninsular Malaysia using ISSR markers (Lee et al. 2018a), selected Aquilaria species from Malaysia using RAPD and SCARS (Lee et al. 2011).

One of natural population of G. versteegii was recently discovered in Manggarai District, Flores Island in a small forest fragment of Pongkor Community Forest (Rindyastuti et al. 2019; Yulistyarini et al. 2019). A species that grow in small and fragmented population generally maintain lower level of genetic variation (Chung 2009; Li and Jin 2006). Genetic variation is the response of organisms in adapting to changed environment condition which leads to adaptation mechanisms. Genetic variation becomes the most important component for efficient species conservation (Frankham et al. 2002). The information on genetic diversity level and its distribution of species are very useful to design the conservation strategies for rare or endangered species (Widyatmoko 2011). On the other hand, Lee et al. (2018b) stated that information on genetic variation of agarwood-producing plants is still very deficient especially in the term of its species and habitat conservation. Therefore, it is necessary to establish the genetic research using molecular markers of related organisms to complete such information. The aims of this study are (i) to confirm the species identity of agarwood producing tree ( $G$. versteegii) found in Pongkor, Manggarai District as well as the phenetic relatedness between individuals. (ii) to determine the genetic variation of agarwood producing tree in Pongkor Community Forest, Pongkor, Manggarai District, Flores Island, East Nusa Tenggara, Indonesia.

\section{MATERIALS AND METHODS}

\section{Procedures}

Sample collection and preparation

Fresh leaves from 12 Gyrinops versteegii's seedling were collected from each sampling point in Pongkor Community Forest, Pongkor, Manggarai District, Flores Island, East Nusa Tenggara with the area of $17 \mathrm{Ha}$ (Yulistyarini et al. 2019) (Figure 1). For the outgroups, plant samples were collected from the nursery of Purwodadi Botanic Garden, Research Centre for Plant Conservation and Botanic Gardens, Indonesian Institute of Sciences (LIPI), Purwodadi, Pasuruan, Indonesia. Samples were stored in a freezer with a temperature of $-20^{\circ} \mathrm{C}$ and removed when DNA isolation process was conducted.

\section{DNA isolation and quantitative analysis}

DNA was extracted from leaf samples using Cetyl Trimethylammonium Bromide (CTAB) method based on Doyle and Doyle (1987) protocol with modifications. DNA purity and concentration were checked quantitatively using Tecan Spark multiplate reader (Tecan, CH) with $\lambda$ 260/280 nm ratio.
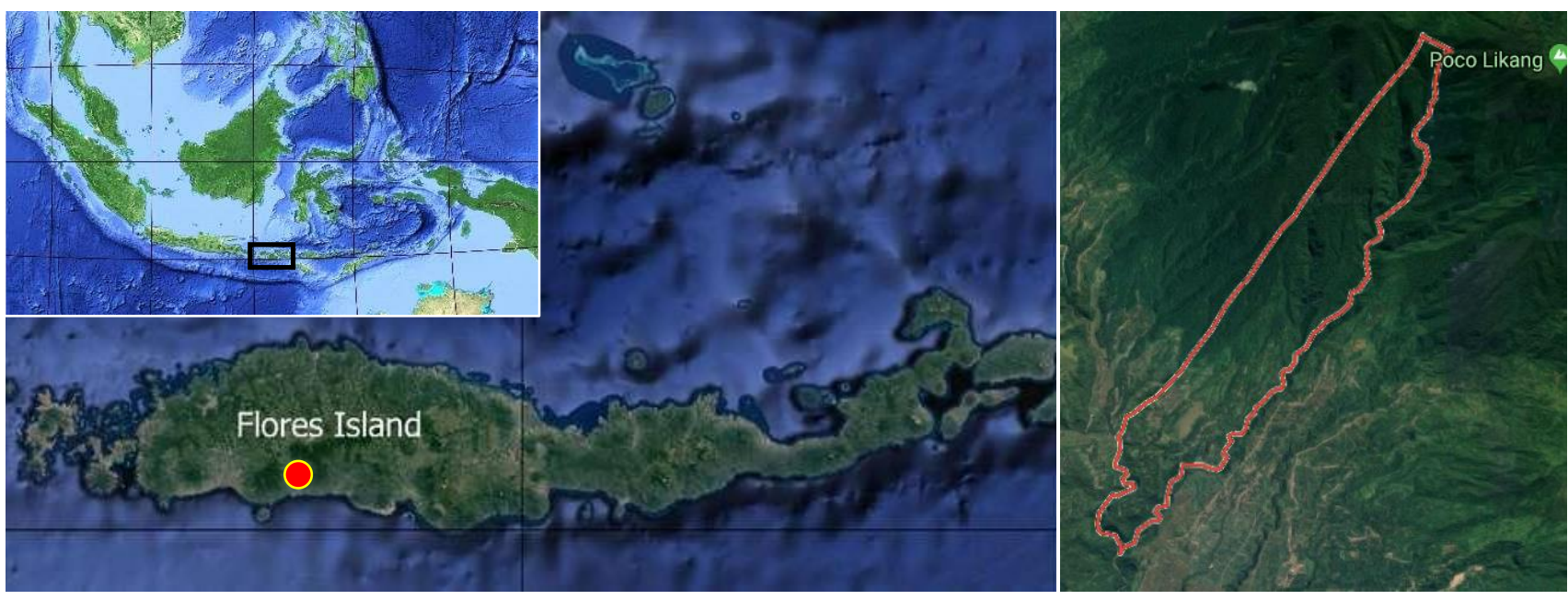

Figure 1. Sampling area of agarwood producing tree (Gyrinops versteegii) in Pongkor Community Forest, Pongkor, Manggarai District, Flores Island, East Nusa Tenggara, Indonesia (Sampling points marked with red dots) 
Table 1. ISSR primers used for genetic analysis of agarwood producing tree (Gyrinops versteegii)

\begin{tabular}{lcc}
\hline Primers & Sequence & Tm $\left({ }^{\circ} \mathbf{C}\right)$ \\
\hline Ng2.01 & (AC)8B & 56.1 \\
Ng2.06 & (CT)8D & 53.6 \\
Ng3.01 & (ACA)5SS & 47.6 \\
Ng3.02 & (AGA)5SS & 53.6 \\
UBC 855 & (AC)8YT & 56.1 \\
\hline
\end{tabular}

\section{DNA amplification with PCR-ISSR}

Five ISSR primers were chosen for DNA amplification from Lee et al. (2018a) which have highest PIC value. Detailed information of the primer's sequence and melting temperature $(\mathrm{Tm})$ are showed in Table 1.

PCR mixture in this research consist of $12,5 \mu \mathrm{L}$ Bioline 2x MyTaq HS Red Mix (Bioline, UK), $2 \mu \mathrm{L} 25 \mathrm{ng} / \mu \mathrm{L}$ for each primers, $2 \mu \mathrm{L} 10 \mathrm{ng} / \mu \mathrm{L}$ DNA samples, $8.5 \mu \mathrm{L} \mathrm{ddH}_{2} \mathrm{O}$ for each reaction (total $25 \mu \mathrm{L}$ per mix). PCR running process was started with initial denaturation at $94^{\circ} \mathrm{C}$ for 10 minutes, denaturation at $94^{\circ} \mathrm{C}$ for 1 minute, annealing at specific temperature based on $\mathrm{Tm}$ for each primer at 1 minute, each process was repeated for 40 cycles. PCR was running then continued by elongation at $72^{\circ} \mathrm{C}$ for 2 minutes, and followed by post elongation at $72^{\circ} \mathrm{C}$ for 10 minutes.

Results of PCR product were analyzed using $2 \%$ agarose gel electrophoresis with fluorosafe DNA Stain (1st BASE, MY) and Thermoscientific GenePlus DNA ladder (Thermo Fisher Scientific, US) $100 \mathrm{bp}$ at 50v for 60 minutes. The results were visualized with GelDoc.

\section{Data analysis}

DNA bands from electrophoresis were converted into matrix of binary data. Present bands were scored as ' 1 ', while absent bands in locus were scored as ' 0 '. Basic parameters as number of locus, monomorphic bands, polymorphic bands, and percentage of polymorphic bands were calculated manually from the matrix. Heterozygosity (h value) based on Nei (1973) from G. versteegii was obtained from the matrix analysis using GenAlEx 6.503. Heterozygosity value was performed using the parameters of $\% \mathrm{P}$ (the number or percentage of polymorphic loci), $\mathrm{He}$ (expected heterozygosity) and uHe (unbiased expected heterozygosity).

Another software used to show phenetic relatedness between individuals was MVSP 3.1. The software of MVSP constructed Unweighted Pair-Group Method with Arithmetic means (UPGMA) based dendrogram, using simple matching coefficient (SSM) clustering analysis.

\section{RESULTS AND DISCUSSION}

\section{Species characteristics and identification}

The Gyrinops genus is distinguished based on the characteristics of its flowers and leaves (Zich and Compton 2001). The species of Gyrinops in this study is $G$. versteegii, which is often exploited in the West Nusa Tenggara and East Nusa Tenggara regions. G. versteegii has oval-shaped leaves, $5-20 \mathrm{~cm} \times 1.5-5 \mathrm{~cm}$, with a short stem that measured around 3-5 mm. The base of the leaf is peg-shaped, the tip of the leaf is pointed out with 12-16 pairs of leaf veins, and the surface of the lower leaves is dull green and the upper part is bright green and shiny. The dry leaves on the lower surface are yellowish-brown, while the upper part of the dry leaves is reddish-brown. The corolla is salverform with the stamen number equal to the petals (i.e. 5) (Hou 1960; Susilo et al. 2014). Based on the field observation, G. versteegii found in Pongkor Community Forest has membranaceous leaves with a bright green color on the upper surface, with 16 pairs of leaf veins, greenish-brown stems, as well as an entire leaf margin. The flowers have tube shaped corolla, with 5 petals and 5 stamens (Yulistyarini et al. 2019).

\section{DNA isolation and quantitative analyses}

DNA was extracted from 12 leaf samples of $G$. versteegii, 2 leaf samples of Gyrinops decipiens, and 2 leaf samples of Aquilaria filaria. DNA concentration and purity from each sample were analyzed quantitatively using Tecan Spark multiplate reader with $\lambda 260 / 280 \mathrm{~nm}$ ratio. Table 2 shows the result of DNA quantitative analysis. The sample of $G$. versteegii is denoted by the code 'RDS,' while the outgroup Gyrinops decipiens sample is denoted by the 'Gd' code, and outgroup A. filaria was denoted by the code of 'Af'.

The DNA concentration was obtained in the range of $120.44-1286.51 \mathrm{ng} / \mu \mathrm{L}$, while the purity ratio $\lambda 260 / 280 \mathrm{~nm}$ showed a range of 1.50-1.92. A great DNA purity ratio for molecular analysis is in the range of 1.8-2.0. A purity ratio below 1.8 can be caused by protein contamination. As for the ratio above 2.0, it is assumed that there is RNA content and phenol, chloroform and urea contamination (Sambrook and Russel 1989). The results of this research, which has 6 RDS samples, including RDS 1, RDS 4, RDS 7, RDS 8, RDS 9, and Af 2, have ratios in the range mentioned above. The other samples have a ratio under 1.8 , but slightly different from Gd 2 that has the lowest ratio. This indicates the presence of protein contamination in the sample. This can be overcome by optimizing pellet washed with alcohol, especially when the centrifugation process takes place, as well as adding polyvinylpyrrolidone (PVP) power on DNA isolation as an antioxidant to bind contaminant compounds (Azhari and Mohamad 2013). The results of DNA samples that have been analyzed quantitatively need to be further tested by running the PCR to determine the quality of the bands formed.

\section{DNA amplification using PCR-ISSR}

Five PCR primers were selected for amplification of the DNA of agarwood producing trees based on the research by Lee et al. (2018a) for the Aquilaria genus. Primers were selected based on reproducibility and the high value of polymorphism information content (PIC). The results of DNA amplification using each primer are shown in Figure 3. 
Table 2. Species, sample codes and quantitative analysis results of agarwood producing tree including ingroup of Gyrinops versteegii and outgroups.

\begin{tabular}{lccc}
\hline Species & Samples & $\begin{array}{c}\text { DNA } \\
\text { concentration } \\
(\mathbf{n g} / \boldsymbol{\mu L})\end{array}$ & $\begin{array}{c}\text { DNA purity } \\
\mathbf{( \lambda \mathbf { 2 6 0 } / 2 8 0 )}\end{array}$ \\
\hline G. versteegii & RDS 1 & 244.90 & 1.87 \\
& RDS 2 & 287.75 & 1.72 \\
& RDS 3 & 311.54 & 1.72 \\
& RDS 4 & 258.89 & 1.89 \\
& RDS 5 & 271.55 & 1.71 \\
& RDS 6 & 382.26 & 1.67 \\
& RDS 7 & 174.35 & 1.92 \\
& RDS 8 & 195.60 & 1.88 \\
& RDS 9 & 373.73 & 1.80 \\
& RDS 10 & 215.39 & 1.78 \\
& RDS 11 & 311.08 & 1.79 \\
& RDS 12 & 120.44 & 1.63 \\
A. filaria & Gd 1 & 1286.51 & 1.55 \\
& Gd 2 & 863.22 & 1.50 \\
& Af 1 & 272.44 & 1.67 \\
& Af 2 & 213.37 & 1.81 \\
\hline
\end{tabular}

The results of DNA amplification in all primers produced clear and reproducible bands in all samples of $G$. versteegii with a total band of 58 with the polymorphic bands percentage of $\mathrm{Ng} 2.01$ primers, $\mathrm{Ng} 2.06, \mathrm{Ng} 3.01$, $\mathrm{Ng3.02}$, and UBC 855 respectively at 69.23\%, 50\%, $64.29 \%$, 40\%, and 54.55\% (Mean: 55.61\%) (Table 3). Overall, all primers showed high genetic information, because the polymorphic percentage showed a value of $\geq$ $50 \%$. The only primer that showed a polymorphic percentage value of less than $50 \%$ was $\mathrm{Ng} 3.02$, implying that $\mathrm{Ng} 3.02$ was not optimally used in the analysis of genetic variation, particularly in $G$. versteegii. Low polymorphic percentage can be caused by similar species from a similar population, therefore the genetic variation obtained will be relatively low.

\section{Clustering analysis}

The results of clustering analysis with UPGMA divide 16 samples consist of $G$. versteegii, $G$. decipiens, and $A$. filaria into 2 main clusters (Cluster A and B) using SSM method. Dendrogram was shown in Figure 4.

Based on the dendrogram, samples of Af 2 and Af 1 form sub-clusters at $72.5 \%$ similarity index, and $\mathrm{Gd} 2$ and Gd 1 which form sub-clusters in the $87.9 \%$ similarity index, which groups on the similarity index of $59.9 \%$, forming cluster A. Cluster B represents all 12 RDS samples clustered on the $85.9 \%$ similarity index, therefore, the similarity index between samples was obtained at a value of $\geq 85.9 \%$. Clusters A and B later grouped on the similarity index of $50.1 \%$.

\section{Heterozygosity}

DNA band scoring data was used for the analysis of heterozygosity (h value) based on Nei (1973). The higher heterozygosity in a population, the higher the genetic diversity of plant species. The results of heterozygosity analysis on $G$. versteegii in Pongkor Community Forest obtained $\% \mathrm{P}$ (the number or percentage of polymorphic loci) at $56.18 \%$ and the $\mathrm{h}$ value in parameters of $\mathrm{He}$ (expected heterozygosity) at 0.218 and uHe (unbiased expected heterozygosity) at 0.227 .
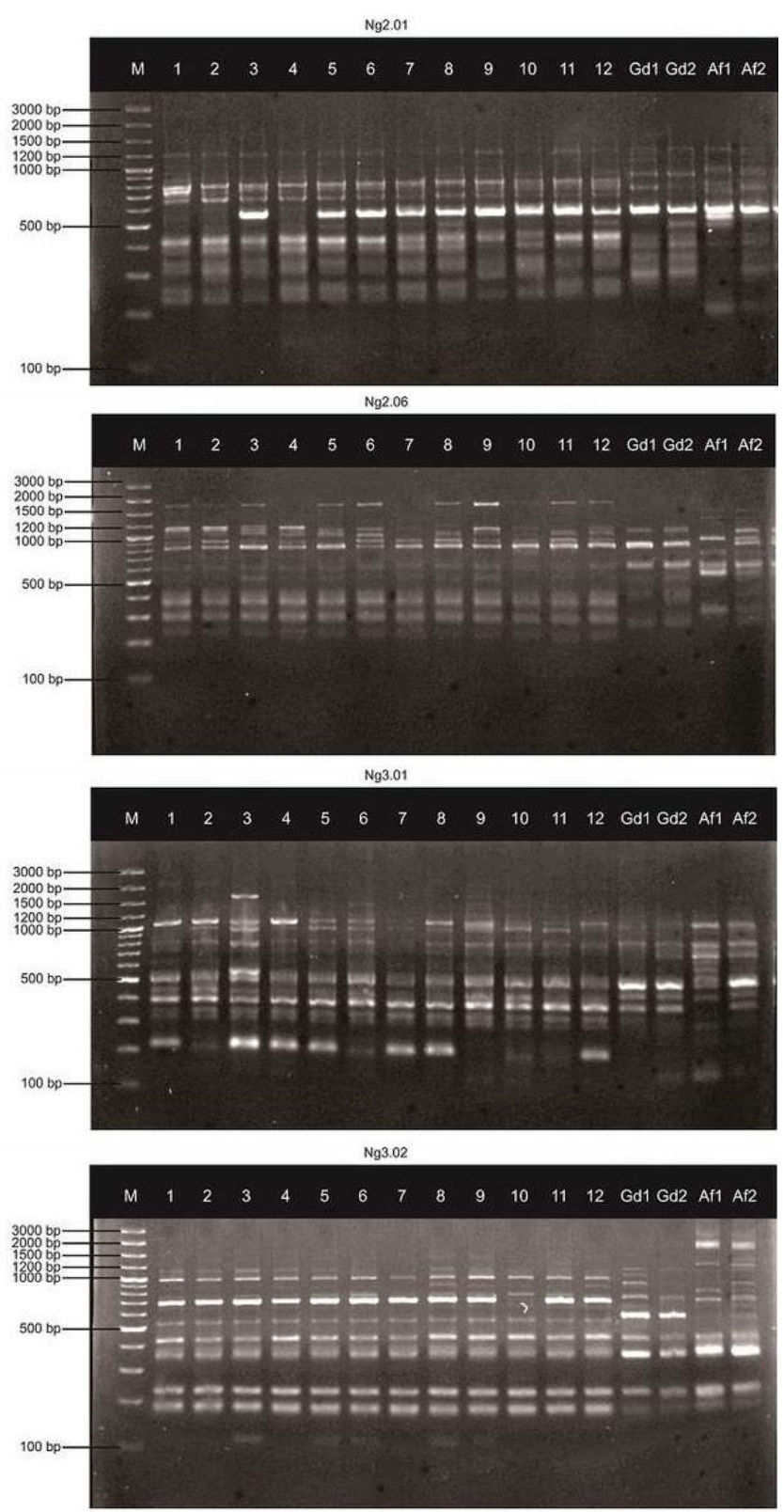

UBC 855

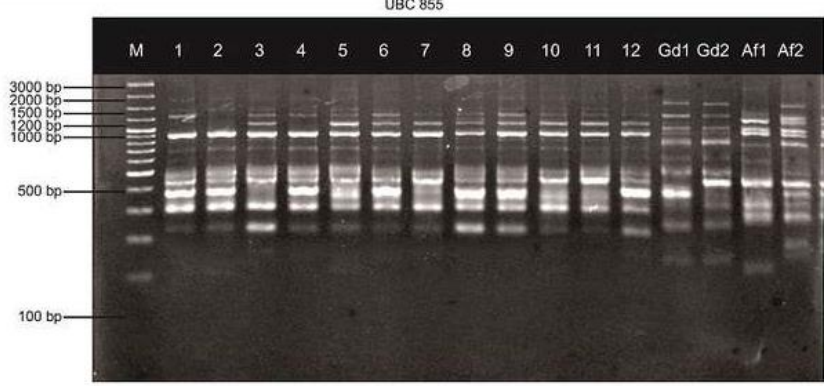

Figure 3. DNA amplification results of 12 samples of Gyrinops versteegii using 5 primers, from top to bottom: $\mathrm{Ng} 2.01, \mathrm{Ng} 2.06$, $\mathrm{Ng} 3.01, \mathrm{Ng} 3.02$, and UBC 855 primer. PCR products were separated by $2 \%$ agarose gel at $50 \mathrm{v}$ for 60 minutes. 
Table 3. The number of DNA strands, monomorphic DNA, polymorphic DNA, PIC value and percentage of polymorphic allele of each primer.

\begin{tabular}{|c|c|c|c|c|c|c|}
\hline Primer & $\begin{array}{c}\text { Primer } \\
\text { Sequence 5'-3, }\end{array}$ & $\begin{array}{c}\text { Number of } \\
\text { DNA strands }\end{array}$ & $\begin{array}{c}\text { Number of } \\
\text { DNA } \\
\text { monomorphic }\end{array}$ & $\begin{array}{c}\text { Number of DNA } \\
\text { polymorphic }\end{array}$ & PIC value & $\begin{array}{l}\text { Percentage of } \\
\text { polymorphic } \\
\text { alleles }(\%)\end{array}$ \\
\hline $\mathrm{Ng} 2.01$ & (AC) $8 \mathrm{~B}$ & 13 & 4 & 9 & 0.46 & 69.23 \\
\hline $\mathrm{Ng} 2.06$ & (CT)8D & 10 & 5 & 5 & 0.47 & 50 \\
\hline Ng3.01 & (ACA)5SS & 14 & 5 & 9 & 0.47 & 64.29 \\
\hline Ng3.02 & (AGA) $5 \mathrm{SS}$ & 10 & 6 & 4 & 0.47 & 40 \\
\hline UBC 855 & (AC)8YT & 11 & 5 & 6 & 0.45 & 54.55 \\
\hline Mean & & & & & & 55.61 \\
\hline
\end{tabular}

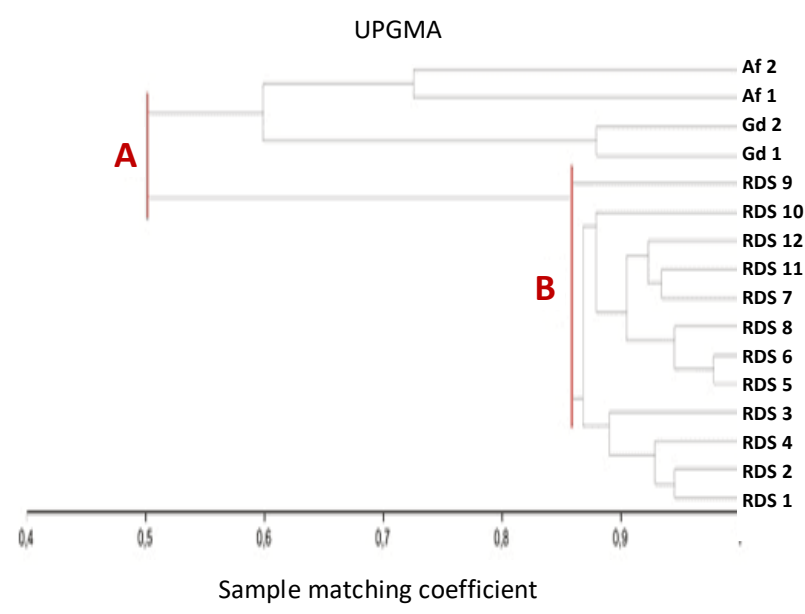

Figure 4. UPGMA clustering analysis of agarwood producing trees using SSM method. The code of RDS is for ingroup Gyrinops versteegii, Af and Gd are for outgroup (A. filaria and Gyrinops decipiens)

\section{Discussion}

Species identification and phenetic relatedness

According to the principle of taxospecies, if the similarity index reaches $\geq 70 \%$, the grouped individuals will be assumed as one species. The greater the value of the similarity index, the closer the phenetic relatedness of species studied (Habich 2001). The result showed that the population found in the forest were properly identified as G. versteegii, a different species from Aquilaria and other Gyrinops species which probably distributed in Flores Island. Twelve samples of $G$. versteegii based on the SSM method, belong to the similar species because they met these taxospecies principles. Moreover, all G. versteegii individuals in Pongkor Community Forest population were assumed to have a very close phenetic relatedness.

Agarwood producing trees including five species i.e. Gyrinops versteegii, $G$. ledermannii $G$. decipiens, $G$. podocarpus, G. caudate, and G. salicifolia (natural habitat in Indonesia and Papua New Guinea) (Roemantyo and Partominharjo 2010; Zich and Compton 2001) and $G$. walla (natural habitat in Sri Lanka) (Schun and Cordell 1985). These species was still taxonomically intricated (Turjaman and Hidayat 2017; Roemantyo and Partomihardjo 2010), especially for two most important genera of agarwood producing tree i.e. Aquilaria and
Gyrinops. These two genera are able to distinguish based on the number of stamen (Hou 1960). In Aquilaria, the number of stamens is twice the number of petals (i.e. 10), while Gyrinops have equal numbers of stamens as petals (i.e. 5). However, the classification basis is debatable because it only uses single character (Zinc and Compton 2001). Paraphyletic taxonomical classification based on the DNA bands using molecular methods (Lee et al. 2018b) and morphological characteristics were established (Wangiyana 2019), therefore some experts noted the need of merging the genus of Aquilaria and Gyrinops as one evolutionary unit (Lee at al. 2018b). Genetic evidence from this study showed lower variation and similarity between plants of Aquilaria and Gyrinops. Based on this result, A. filaria is grouping with Gyrinops decipiens and $G$. versteegii on the similarity index below $70 \%$ (50.1\%), indicating high variations among three species based on the taxospecies principle. The result of this study is quite different from other previous studies which showed high similarity between Aquilaria and Gyrinops plants. The study using broader samples of two genera, combining other taxonomical evidence such as morphology, anatomy, etc. is needed to construct reliable taxonomic classification (Lee et al. 2018b).

\section{Genetic variation of Gyrinops versteegii}

A population can be considered to have a high genetic diversity value if it has a high percentage of polymorphism and high expected heterozygosity value (Frankam et al. 2002). DNA band scoring data was used for the analysis of polymorphism and heterozygosity (h value) based on Nei (1973). Low heterozygosity value indicates scarcity of genetic variation of organisms in the wild population, therefore it serves as an important parameter in determining conservation strategies of plant species (Siburian et al. 2017). Many previous studies classified the value of heterozygosity more than 0.20 for common plant families, especially rare species as high (Hamrick and Godt 1996). Nei's genetic diversity of endangered and endemic species with limited distribution range is not expected to be high, because, the relationships between population size, plant fitness, and genetic diversity are generally significantly positive (Leimu et al. 2006). Many studies reported relatively high genetic diversity of rare species such as in Tuberaria major (0.197) (Trindade et al. 2012), rare and endemic orchids of Vanda foetida (0.1999 and 0.1778) (Rindyastuti et al. 2015) and rare medicinal plant Magnolia 
officinalis (0.342) (Yu et al. 2011), vulnerable woody species from Sulawesi Diospyros celebica (0.28) (Widyatmoko et al. 2011).

The results of polymorphism percentage and heterozygosity analysis on $G$. versteegii in Pongkor Community Forest obtained at $56.18 \%$ and $\mathrm{h}$ value in the parameters of $\mathrm{He}$ at 0.218 and uHe 0.227. The polymorphism percentage was classified as moderate, because other previous study obtained $\% \mathrm{P}$ at more than 70\% (Rindyastuti et al. 2015; Yu et al. 2011). Compared to other endangered and endemic species, the $\mathrm{h}$ value of $G$. versteegii obtained in this study is high. Other research results by Siburian et al. (2017) revealed that the heterozygosity values of $G$. versteegii in Kebar, West Papua, and Manokwari, West Papua were obtained at 0.2944 and 0.2357 , respectively. This value is slightly greater than heterozygosity of G. versteegii in Pongkor Community Forest. However, it can be assumed that the genetic variation of $G$. versteegii in Pongkor Community Forest is still within the common range of the species. Compared to $h$ value of other agarwood producing tree, $h$ value obtained from this study was higher than $h$ value of A. malaccensis from Assam, India which was obtained at 0.14 (Banu et al. 2015). Nonetheless, the research of Singh et al. (2015) showed that other agarwood-producing species, A. malaccensis had heterozygosity values in the range of $0.597-0.811$. This shows that the heterozygosity value of $G$. versteegii is relatively high however could be increased to the level of higher plant fitness $(>0.30)$ by endorsing reliable conservation programs.

Habitat fragmentation negatively affects genetic variation and plant fitness (Leimu et al. 2006). The result of this study showed that $G$. versteegii in Pongkor which growing upon the remnant forest fragment in the small area of $17 \mathrm{Ha}$ should be a priority in the conservation programs because although it has relatively high genetic diversity, the natural population is threatened by environmental changes, habitat distraction by human and other forest disturbances. Beside establishing habitat preservations, conservation strategy could be established by maintaining and increasing population size of $G$. versteegii in Pongkor Community Forest through plant propagation and reintroduction (Falk and Holsinger 1991). The plants of $G$. versteegii from Pongkor Community Forest could be recommended as the source of species propagation and reintroduction, however, needed to increase its genetic variation using cross-pollination among individual withinpopulation or inter-population both naturally and artificially. Cross-pollination supports the plants to have random mating within-population which could maintain genetic variation of plant species. Moreover, collecting seed and transferring seedling from other populations could also increase the gene flow among population of $G$. versteegii in Flores Island.

In conclusion, the plant samples in this population were properly identified as $G$. versteegii and have very close phenetic relatedness among the individual, indicating that there are no significant gene differences. All primers showed relatively high genetic variation of $G$. versteegii in Pongkor Community Forest population. Heterozygosity values were relatively high, slightly different from the common range of the species but lower compared to those other species. Genetic variation of $G$. versteegii which growing in smaller populations implying the need for maintaining larger population size to obtain high genetic diversity and species fitness.

\section{ACKNOWLEDGEMENTS}

This research was supported by CITES project year 2019 with the title "Studi Populasi dan Pola Sebaran JenisJenis Pohon Penting Terdaftar Appendix II CITES: Gaharu (Gyrinops versteegii (Gilg.) Domke), Sonokeling (Dalbergia latifolia Roxb.) dan Angsana (Pterocarpus Indicus Willd.)", conducted by Purwodadi Botanic GardenLIPI and Research Centre for Biology-LIPI. A part of this research is also funded by RTA grant no: 2129/Un1/ DITLUT/DIT-LIT/LT/2019.

AFI was mentioned as first author for mainly doing the research thesis and wrote the manuscript. $R R$ as a team leader of the CITES project facilitated the funding, developed the research concept and wrote the discussion. TY and ASD validated the field data and discussion, especially for conservation implication. BSD wrote and verified research method, scientific framework, and finding.

\section{REFERENCES}

Akter S, Islam MT, Zulkefeli M, Kham SI. 2013. Agarwood production-A multidisciplinary field to be explored in Bangladesh. Intl $\mathrm{J}$ Pharmaceut Life Sci 2 (1): 22-32.

Allendorf, FW, Luikart G, Aitken SN. 2013. Conservation and The Genetics of Populations. Wiley-Blackwell, New Jersey.

Azhari MH, Mohamad A. 2013. Crucial optimization steps in getting premier quality of Aquilaria malaccensis genomic DNA for molecular activities. INIS 45 (43): 1-9.

Banu S, Baruah D, Bhagwat RM, Sarkar P, Bhomwick A, Kadoo NY. 2015. Analysis of genetic variability in Aquilaria malaccensis from Bramhaputra Valley, Assam, India using ISSR markers. Flora 217: 24-32

Barden A, Anak NA. 2002. Heart of the Matter: Agarwood Use and Trade and CITES Implementation for Aquilaria malaccensis. TRAFFIC International, Cambridge.

Chung MY. 2009. Low levels of genetic variation within populations of the four rare orchids Gymnadenia cucullata, Gymnadenia camtschatica, Amitostigma gracile, and Pogonia minor in South Korea: indication of genetic drift and implications for conservation. Plant Syst Evol 281: 65-67.

CITES. 2017. Appendices I, II and III. https: //www.cites.org/eng/app/appendices.php.

Dahham SS, Tabana YM, Hassan LE, Ahamed MBK, Majid ASA, Majid AMSA. 2016. In vitro antimetastatic activity of Agarwood (Aquilaria crassna) essential oils against pancreatic cancer cells. Alexandria J Med 52: 141-150.

Daryono BS, Subiastuti AS, Fatmadanni A, Sartika D. 2019. Phenotypic and genetic stability of new Indonesian melon cultivar (Cucumis melo L. 'Melonia') based on ISSR markers. Biodiversitas 20 (4): 10691075

Doyle JJ, Doyle JL. 1987. A rapid DNA isolation procedure for small quantities of fresh leaf tissue. Phytochem Bull 19: 11-15.

Falk DA, KE Holsinger. 1991. Genetics and conservation of rare plants. Oxford University Press, New York.

Frankham R, Ballou JD, Briscoe DA. 2002. Introduction to Conservation Genetics. Cambridge University Press, Melbourne. 
Godwin ID, Aitken EAB, Smith LW. 1997. Application of inter simple sequence repeat (ISSR) markers to plant genetics. Electrophoresis 18 (9): 1524-1528.

Habich EF. 2001. Ecological Site Inventory, Technical Reference 1734-7. Bureau of Land Management, Colorado, USA.

Hamrick JL, Godt MJW. 1996. Effects of Life History Traits on Genetic Diversity in Plant Species. Phil Trans R Soc B: Biol Sci 351 (1345): 1291-1298.

Hou D. 1960. Thymelaeaceae. In: Van Steenis CGGJ. (ed.), Flora Malesiana Series I, Vol 6. Wolter-Noordhoff Publishing, Groningen, Netherlands.

Lee SY, Ng WL, Lamasudin DU, Mohamed R. 2018a. Inter-simple sequence repeat markers reveal genetic relatedness between natural Aquilaria populations in Peninsular Malaysia. Chiang Mai J Sci 45 (3): 1307-1317.

Lee SY, Turjaman M, Mohamed R. 2018b. Phylogenetic relatedness of several agarwood-producing taxa (Thymelaeaceae) from Indonesia. Trop Life Sci Res 29 (2): 13-28.

Lee SY, Weber J, Mohamed R. 2011. Genetic Variation and Molecular Authentication of Selected Aquilaria Species from Natural Populations in Malaysia Using RAPD and SCAR Markers. Asian J Plant Sci 10: 202-211.

Leimu R, Mutikainen P, Koricheva J, Fischer M. 2006. How general are positive relationship between plant population size, fitness and genetic variation? J Ecology 94: 942-952.

Li J-M, Jin Z-X. 2006. High genetic differentiation revealed by RAPD analysis of narrowly endemic Synocalycanthus chinensis Cheng et SY Chang, an endangered species of China. Biochem Syst Ecol 34 (10): $725-735$

López-Samson A, Page T. 2018. History of use and trade of agarwood. Econ Bot 72 (1): 107-129.

Nei M. 1973. Analysis of gene diversity in subdivided populations. Proc Natl Acad Sci USA 70 (12): 21-23.

Okugawa H, Ueda R, Matsumoto K, Kawanishi K, Kato A. 1993. Effects of agarwood extracts on the central nervous system in mice. Plant Med 59 (1): 32-36

Richard G, Kerrest A, Dujon B. 2008. Comparative genomics and molecular dynamics of DNA repeats in eukaryotes. Microbiol Mol Biol Rev 72 (4): 686-727.

Rindyastuti R, Metusala D, Kumalawati DA, Daryono BS. 2015. Genetic variation of Vanda foetida J.J.Sm.; a rare and endemic orchid in South Sumatra based on RAPD analysis. J Trop Biol Conserv 12: 99-112.

Rindyastuti R, Yulistyarini T, Darmayanti AS. 2019. Population and ecological study of agarwood producing tree (Gyrinops versteegii) in Manggarai District, Flores Island, Indonesia. Biodiversitas 20 (4): 1180-1191.

Roemantyo, Partomihardjo T. 2010. Analisis prediksi sebaran alami gaharu marga Aquilaria dan Gyrinops di Indonesia. Berita Biologi 10 (2): 189-205. [Indonesian]

Sambrook J, Russel DW. 1989. Molecular Cloning: A Laboratory Manual $2^{\text {nd }}$ ed. Cold-Spring Harbor Laboratory Press, New York.

Schun Y, Cordell GA. 1985. Studies in the Thymelaeaceae III. Constituents of Gyrinops walla. J Nat Prod 48 (4): 684-685.
Semagn K, Bjørnstad A, Ndjiondjop MN. 2006. An overview of molecular marker methods for plants. African J Biotechnol 525 (25): 2540-2568.

Siburian RHS, Siregar UJ, Siregar IZ. 2017. Genetic variation of Gyrinops versteegii originated from Papua based on RAPD. Asian J Microbiol Biotech Env Sci 19 (3): 1-9.

Sidiyasa K. 1986. Jenis-jenis tumbuhan penghasil gaharu. Jurnal Penelitian dan Pengembangan Kehutanan Bogor 2 (1): 7-16. [Indonesian]

Singh P, Sharma H, Nag A, Bhau BS, Sharma RK. 2015. Development and characterization of polymorphic microsatellites markers in endangered Aquilaria malaccensis. Conserv Genet Resour 7 (1): 61 63.

Sitepu IR, Santoso E, Turjaman M. 2011. Identification of Eaglewood (Gaharu) Tree Species Susceptibility. Badan Penelitian dan Pengembangan Kehutanan. Jakarta. [Indonesian]

Susilo A, Kalima T, Santoso E. 2014. Panduan Lapangan Pengenalan Jenis Pohon Penghasil Gaharu Gyrinops spp. di Indonesia. IPB Press, Bogor. [Indonesian]

Trindade H, Sena I, Goncalves S, Romano A. 2012. Genetic diversity of wild populations of Tuberaia major (Cistaceae), and endangered species to the Algarve region (Portugal), using ISSR markers. Biochem Syst Ecol 45: 49-56.

Turjaman M, Hidayat A, Santoso E. 2016. Development of agarwood induction technology using endophytic fungi. In: Mohammed R (eds). Agarwood, Science Behind the Fragrance. Springer Science+Bussiness Media, Singapore.

Turjaman M, Hidayat A. 2017. Agarwood-planted tree inventory in Indonesia. IOP Conf Ser: Earth Environ Sci 54 (2017) 012062. DOI: 10.1088/1755-1315/54/1/012062

Wangiyana IGAS. 2019. Similarity Analysis of genera Aquilaria and Gyrinops based on vegetative structure feature using different clustering methods. Jurnal Sangkareang Mataram 5 (1): 62-68.

Widyatmoko AYPBC, Afrianti RD, Taryono T, Rimbawanto A. 2009. Keragaman genetic lima populasi Gyrinops verstegii di Lombok menggunakan Penanda RAPD. Jurnal Pemuliaan Tanaman Hutan 3 (1): 1-10. [Indonesian]

Widyatmoko AYPBC, Nurtjahjaningsih ILG, Prastyono. 2011. Study On The Level Of Genetic Diversity of Diospyros celebica, Using RAPD Markers. ITTO Project PD 539/09 Rev.1 (F) in Corporation with Center for Conservation and Rehabilitation Research and Development, Forestry Research and Development Agency, Ministry of Forestry, Bogor.

Yulistyarini T, Rindyastuti R, Darmayanti AS, Budiharta S, Fiqa AP, Siahaan FA. 2019. Studi habitat dan variasi morfologi gaharu (Gyrinops versteegii (Gilg) Domke) di Kabupaten Manggarai, Flores. Prosiding Seminar Konservasi dan Pemanfaatan Tumbuhan dan Satwa Liar, Pusat Penelitian Biologi-LIPI, Bogor. [Indonesian]

Zich F, Compton J. 2001. Agarwood (gaharu) harvest and trade in Papua New Guinea: A preliminary assessment. CITES document. TRAFFIC Oceania, Sydney. 